\title{
建物内 $\mathrm{T}$ 字路における避難経路選択に通路幅員が与える影響 AN EFFECT OF PASSAGE WIDTH ON CHOICE OF EGRESS ROUTE
AT A T-JUNCTION IN A BUILDING
}

\author{
林 広明*, 室崎 益輝**, 西垣太郎*** \\ Hiroaki HAYASHI, Yoshiteru MUROSAKI and Taro NISHIGAKI
}

\begin{abstract}
The purpose of this study is to evaluate quantitatively the effect of a passage width on choice of egress route at a T-junction. Two experiments were carried out to clarify the behavior of egress under forrowing two conditions. (i) Showing subjects VTR images of T-junction under the limited information of egress route. (ii) Using the simulator system driven by the subjects themselves under the condition that subjects can search for information of egress route freely. From results of the experiment, following two points became clear. (1) Almost $70 \% \sim 90 \%$ of the evacuees can be led to safety egress without emergency guide lights or emergency guidance, when the relative ratio of the width of the right passage at a $\mathrm{T}$-junction to that of the left one is approximately $1.7 \sim 2.5$. (2) There is no difference in choice ratio of a wide passage, in case that relative ratio of the width at a $\mathrm{T}$-junction is over 2.5 .
\end{abstract}

Keywords : egress route, passage width, T-junction, simulator, VTR images 避難経路, 通路幅員, T字路, シミュレータ, VTR 映像

\section{1.はじめに}

通路構成が複雑化した建物から滞在者を安全に避難さ せるためには，火煙に対する避難経路の安全性を高める と同時に, 迷うことなく出口まで到達できる避難経路を 設計する必要がある。そのためには, 基本設計の段階か ら避難計画を考慮して建築計画を進めるのが合理的であ る.

現在法規的には, 避難計画について2万向避難の確保, 避難出口までの歩行距離制限, 通路幅員の確保, 避難誘 導灯の設置などが規定されている。しかし，これらの規 定を遵守するだけでは十分な安全性が確保されたとはい えない.人間の行動特性を考慮してて通路計画を行い, 避 難誘導効果を持った建築空間を創出するなど,さらに高 い安全性を考慮する必要がある。例えば，避難行動特性 上選択されやすい形態の通路計画を行えば，建築空間自 体が避難誘導効果を持ち, 複雑な通路構成でも避難に支 障をきたさないようにすることができる。

しかし, 実際にはこのような避難行動特性からみた避
難経路の有効な形状等の提案が行われた例はほとんどな い.その理由は，どの様な条件のときに避難行動特性が 顕在化するのかが定量的に示されていないためである。 火災時の避難行動を扱った研究は，これまでにも様々 なアプローチで行われてきた. 火災発生後の被災者への ヒヤリング・アンケートに基づく調査研究は, 1932年の 白木屋火災を初めとして, 以降, 千日ビル1), 大洋デパー ト2), ホテルニュージャパン3〉などの多〈の死傷者を出 した火災事例について行われてきた4)。このような研究 は海外に扔いても MGMグランドホテル火災5)などで行 われている.また,これらの調查結果を元に避難行動を 構造的に把握するための研究が行われ，帰巣性，向光性， 向開放性などの行動特性が指摘された6)，7). 北後8) は過 去の火災時の避難行動調査事例を元にその類型化を行 い, 建築物の空間特性, 利用形態と避難状況との関係を 明らかにした. 以上の研究は避難行動特性を定性的に示 したという点で重要であるが, 空間特性と避難行動特性 との関係を定量的に関連づけるには至っていない.

\footnotetext{
本論文の内容の一部は, 1995年度日本建築学会大会で発表している ${ }^{18) 。 ~}$

*神戸大学大学院自然科学研究科 大学院生・ Graduate School of Science and Technology, Kove Univ., M. Eng. 工修

***神戸大学工学部建設学科 教授. 工博

*** 大成建設侏技術研究所 “博 
一方, 避難時の行動特性を把握することを目的とした 実験も多数行われている9)-15).これらの研究を通して， 歩行速度や避難誘導灯の見通し距離, 階段の有効幅員な どについては定量的に把握されたが, 経路選択行動につ いては定性的傾向が把握されたに留まっている。

平常時における経路選択行動に的を絞った研究も行わ れているが(6)、17)，ここでも経路選択行動特性が定量的に 示された例はない.

本研究では, 避難経路選択行動特性のうち向開放性に 焦点を絞り，この特性が顕在化するための条件を定量的 に示すことを目的とし，T字路を対象に行った 2 種の被 験者実験について報告する。

\section{2. 避難方向を判断するための情報を制限した場合 （VTR 映像提示による実験）}

実際に避難方向を判断する場合には通路幅員だけでは なく，通路を曲がった先の状況も重要な要因となる。し かしここでは通路幅員が及ぼす影響のみについて検討 するため, 通路を曲がった先の状況に関する情報を与え ない条件で実験を行った。

\section{1 実験概要}

\subsubsection{VTR 映像}

実験は, T字路に向かって進むVTR映像を被験者に提 示し，その視覚情報から避難したい方向を判断させた。

映像は縮尺 $1 / 30$ の模型内通路を CCD カメラを移動さ せて撮影したものである. 避難方向を判断するために被 験者が利用できるのは，図-1に矢印で示すように直線通 路から見たT字路の左右の幅員についての視覚情報のみ であり，曲がった先の状況は分からない。

撮影に使用したカメラの画角は，水平方向 $111^{\circ}$ ，垂 直方向 $88^{\circ}$ である.カメラの移動速度は $35 \mathrm{~mm} / \mathrm{sec}$ (実際 の空間では $1.05 \mathrm{~m} / \mathrm{sec} に$ 相当する）に設定した。この速度 は避難計算で一般に用いられる歩行速度 $1.0 \mathrm{~m} / \mathrm{seckほほ}$ 等しいものである.このように撮影した映像を, 100inch

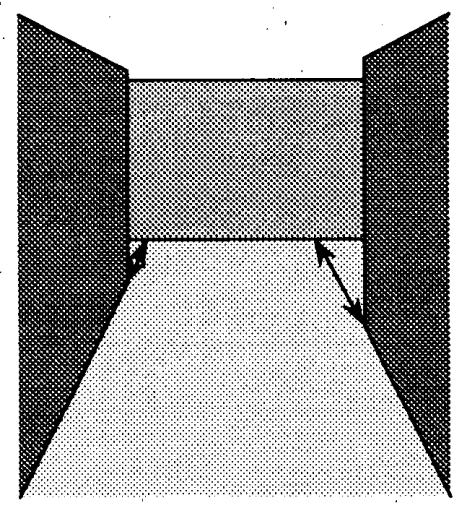

図 -1 避難方向を判断するための視覚情報
モニターに提示した。

\section{1 .2 実験条件}

丁字路において通路の広さについての判断は, 図-2に 示すように，狭幅員通路に対する広幅員通路の幅員の相 対比に依存すると考える. そこで，この実験では相対比 として $1.0 １ .3 １ .5,1.7,2.0,2.5,3.007$ 種を設定し た。これと, 左右通路幅員の入れ替え, T字路に向かう 直線通路（進入路）の幅員の影響を考慮して, 48 通りの 左右通路幅員の組み合せを設定した。

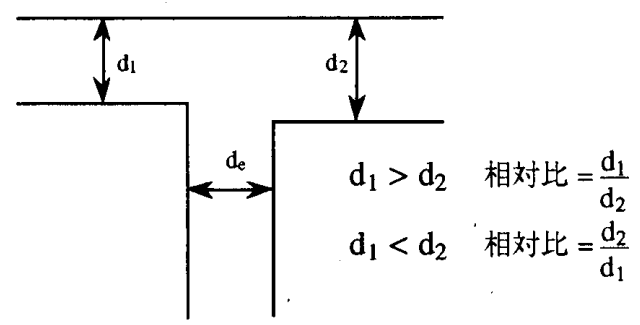

図 -2 左右通路幅員の相対比の定義

\subsection{3 実験手順}

実験は以下の手順で行った。

(1)実験条件となる48通りの左右通路幅員を組み合わせた 映像を撮影し，それぞれの映像の間隔が5秒程度にな るように編集した。

(2)被験者 4 6人を 1 グループとして，100inch モニター の前に座らせた。

(3)実験を始める前に，被験者に以下の教示を与えた。

- 本実験は火災時の建物からの避難を想定しているの でできるだけ早く判断する。

、丁字路に向かって進む映像が映写されるので，映像 が切れるまでに左右どちらに進むかを判断し，用紙 にチェックする。

(4)サンプル映像を提示し, 試験的に回答を行わせ, 被験 者に実験の要領が理解できたかどうかを確認した後, 本実験を行った。

2.1.4 被験者

被験者は 20 代～ 50 代の男女 42 名であった。 その内訳 を表-1に示す. 20代男性のうち2名は建築防災関係の研 究に従事するものであり, 避難行動特性に関する知識を 有していたが, それ以外のものは防災に関する知識はそ しW.

表-1 被験者の属性分布

\begin{tabular}{c|c|c|c}
\hline 性別 & $\begin{array}{c}\text { 男性 } \\
\text { (人) }\end{array}$ & $\begin{array}{c}\text { 女性 } \\
\text { (人) }\end{array}$ & $\begin{array}{c}\text { 合計 } \\
\text { (人) }\end{array}$ \\
\hline 年齢 & 10 & 7 & 17 \\
\hline 20 歳代 & 10 & 8 & 8 \\
\hline 30 歳代 & 0 & 8 & 8 \\
\hline 40 歳代 & 0 & 8 & 8 \\
\hline 50歳代 & 0 & 9 & 9 \\
\hline 合計 (人) & 10 & 32 & 42 \\
\hline
\end{tabular}




\section{2 実験結果および考察}

\subsection{1 広幅員通路の選択率}

T字路における各左右通路幅員相対比での広幅員通路 選択率を図-3に示す. 左右通路幅員の相対比 1.3 以上で は，広幅員通路選択率はいずれの相対比に扔いても $90 \%$ を超える高い值になっており，広いと感じられる通路を 選択する傾向が見られる。

相対比の変化に伴う選択率の変化の状況をみると, 1.3 1.7の間では相対比が高くなるに従って広幅員通路 の選択率も高くなる傾向があるが, 相対比 1.7 を超える 部分では 95\%程度で横這いになっている。このことか ら，この実験結果では T字路に扔ける左右通路幅員相対 比を 1.7 より大きくしても，広幅員通路への誘導効果は 変わらないと考えられる。

\subsection{2 左右通路幅員が等しい場合の選択傾向}

表-2に示すように,いずれの場合においても左側通路 の選択率は40\%を下回っており，右側通路の選択傾向が 見られる.従来, 避難行動特性として左回り傾向がある といわれているが，この実験では逆の傾向が示された。 その原因として，選択方向のチェックを筆記式としたた め利き腕の影響を受けたとも考えられるが，今後検討が 必要である。

\subsection{3 進入路幅員が経路選択に与える影響}

図-4に進入路幅員が異なる場合の各左右通路幅員の相 対比に扔ける広幅員通路選択率を示す. 全体の傾向とし て、いずれの進入路幅員においても相対比が高くなるに 従って広幅員通路選択率も高くなっており,この傾向に 進入路幅員による影響はないと考えられる。

また，進入路幅員が $10 \mathrm{~cm}$ （実際の空間では $3.0 \mathrm{~m}$ に相 当）および $16.7 \mathrm{~cm}$ （同 $5.0 \mathrm{~m}$ ）のときに，広幅員通路選択 率が他の進入路幅員の場合と比較して高くなっている. このことから,より効果的に避難者を広幅員通路に誘導 することができる最適な進入路幅員が存在することが予 想される. 今回の実験結果からはその範囲は $3.0 \mathrm{~m} \sim 5.0 \mathrm{~m}$ であると考えられる。

\subsection{4 広幅員通路の左右の配置が経路選択に与える影響}

T字路において広幅員通路が右にある場合と左にある 場合の広幅員通路選択率を図-5に示す．相対比 1.7 以上 では広幅員通路が右にあっても，左にあっても各相対比 に打ける広幅員通路選択率に違いは見られない。

相対比 1.5 以下では広幅員通路が右にある場合の選択 率が高くなっている。これは左右通路幅員が等しい場合 にみられた右側通路選択傾向の影響と考えられる。相対 比 1.7 以上では，この影響がみられなくなっていること から, 右側通路選択傾向は T字路の左右通路幅員の相対 比が 1.5 以下の場合に強く現れるものと考えられる.

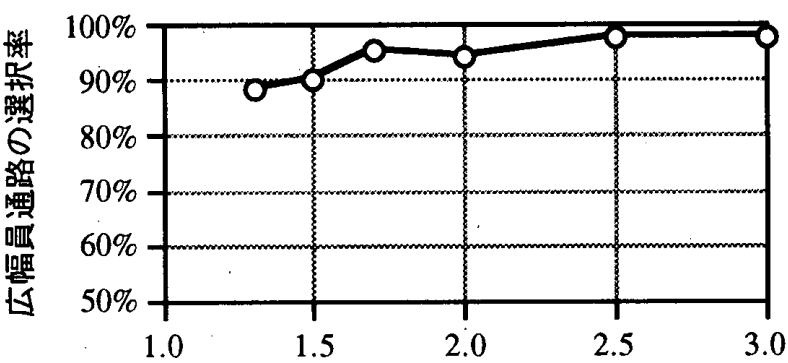

左右通路幅員の相対比

図-3 各相対比における広幅員通路選択率

表-2 左右通路幅員が等しいときの左側通路選択率

\begin{tabular}{|c|c|c|c|c|c|}
\hline \multirow{2}{*}{$\begin{array}{c}\text { 進入路幅貝 } \\
\operatorname{de}(\mathrm{cm}) \\
\end{array}$} & \multirow{2}{*}{\begin{tabular}{|c} 
左右通路幅貝 \\
$\operatorname{di}(\mathrm{cm})$
\end{tabular}} & \multicolumn{3}{|c|}{ 各通路の選択数（人） } & \multirow{2}{*}{\begin{tabular}{|c|} 
左側通路の \\
選択率(\%) \\
\end{tabular}} \\
\hline & & 左 & 右 & 合計 & \\
\hline 6.0 & 6.0 & 15 & 27 & 42 & 36 \\
\hline 12.0 & 12.0 & 15 & 27 & 42 & 36 \\
\hline 18.0 & 18.0 & 12 & 30 & 42 & 29 \\
\hline & 合 & 42 & 84 & 126 & 33 \\
\hline
\end{tabular}

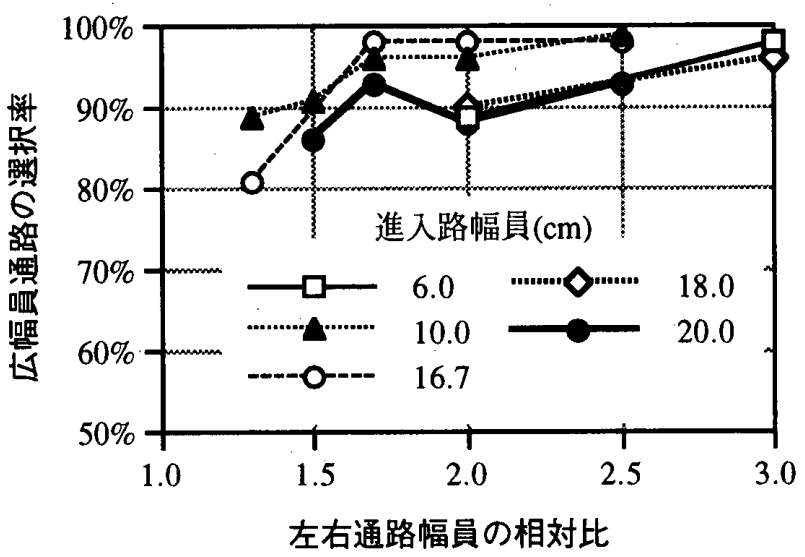

図-4 各進入路幅員に扮汁る広幅員通路選択率

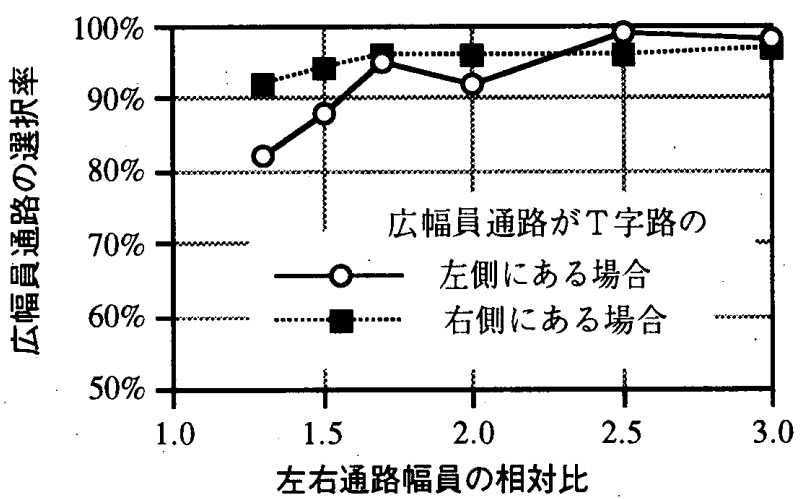

図-5 広幅員通路が右にある場合と 左にある場合の広幅員通路選択率

\section{3. 避難方向の判断するための情報の制限をしない場合} （模型シミュレータによる実験）

VTR映像による実験では, 直線通路をT字路に向かっ て直進する部分しか提示されなかったため, T字路に達 する前に進む方向を判断しなければならなかった。従っ て，T字路を曲がった先の状況にかかわりなく，直線通 
路から見た左右通路の幅員についての視覚情報のみで進 路を判断したことになる。しかし，実際にはT字路にい たるまでの行動や曲がった先の状況も避難方向の判断に 影響を与えると考えられる。

本章では，个字路での避難方向の判断について被験者 が必要な情報を自由に探索できる場合の選択傾向を把握 することを目的に, 被験者が操作する模型シミュレータ を用いて実験を行った。

\section{1 実験概要}

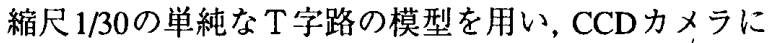
よるシミュレータシステムを利用して被験者実験を行っ た。以下に実験に用いたシミュレータおよび模型の概要 を述べる。

3.1.1 シミュレータシステムの概要

シミュレータシステムは図-6に示すような構成になっ ている。シミュレータ装置の概要を表-3に示す. CCDカ メラの移動速度は $35 \mathrm{~mm} / \mathrm{sec}$ であり, 奏際の空間では $1.05 \mathrm{~m} / \mathrm{sec}$ に相当する. 照明には 20 型蛍光灯4基を用いた。

CCDカメラの移動は, 常にカメラの正面方向に進むよ うにコンピュータで制御した。すすなわち，右折あるいは 左折をしようとする場合には、いったんカメラを曲がり たい方向に回転させ，それから前進するという手順を踏 むことになる。

カメラからの映像は別室の 39 型ワイド画面 TV モ二 ターに映した．被験者はこの映像を見ながらジョイス ティックでカメラを操縦した。

\section{1 .2 実験条件}

模型は単一のT字路とし, 図-7に示すように, 進入路 の通路幅員と T字路の左右どちらか一方の通路幅員との 比が 1.0 : 1.0 となるようにした. 広幅員通路は，実験条 件の偏りを避けるため, T字路の左右にランダムに配置 した，図中の黒丸は出口の位置を示す．

$\mathrm{T}$ 字路において通路の広さについての判断は, 前節と 同様に左右通路の相対比に依存すると考え，T字路にお ける左右通路の相対比として $1.0 \sim 3.0$ の間で 8 種を設定 した，相対比の定義は前節と同様である。実験条件には 進入路の通路幅員も考慮し，11通りを設定した。各グ ループの実験条件を表-4に示す。

被験者を G1，G2の 2 グループに分け，それぞれのグ ループでT字路の左右通路幅員を入れ替えて実験を行っ た. 例えば, 左右通路幅員が $10 \mathrm{~cm}$ と $13 \mathrm{~cm}$ の組合わせで ある場合，G1グループでは図-7のように左 $13 \mathrm{~cm} ・$ 右 10 $\mathrm{cm}$ と、 $\mathrm{G} 2$ グループでは左 $10 \mathrm{~cm} \cdot$ 右 $13 \mathrm{~cm}$ とした。

\subsection{3 実験手順}

実験は以下の手順で行った.

(1)被験者一人ひとりを実験室に案内し，以下の教示を

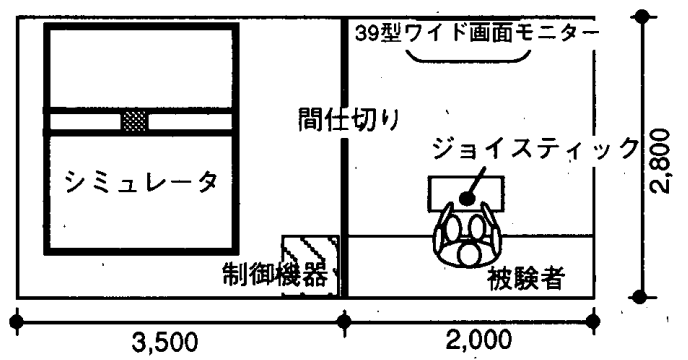

図-6 シミュレータシステムの構成

\begin{tabular}{|c|l|}
\multicolumn{2}{c|}{ 表-3 } \\
\hline
\end{tabular}

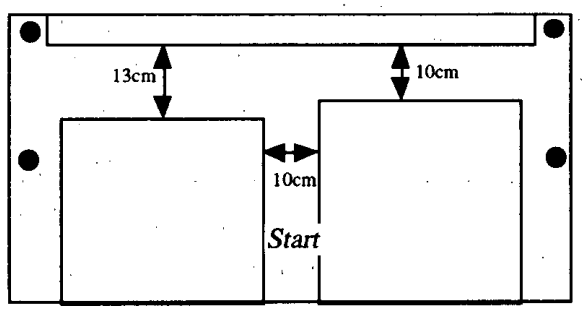

図-7 模型通路の幅員の組合せの例

表-4 模型シミュレータ実験における実験条件

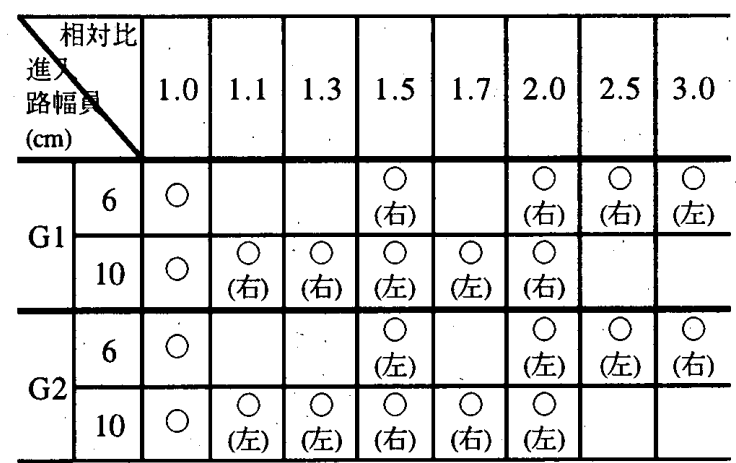

注)表中の○印は設定した実験条件を示す。

表中の左右は広幅員通路を配置した方向を示す。

行った。

・この実験は火災時の避難を想定しているので，できる だけ早く出口までたどり着く.

. 模型は建物内の通路を想定しているので, 出口は何力 所かある。

・出口は床面に緑色のジールを貼って示してあり，その 印にたどり着いた時点で終了とする。

(2)図-7 中の Start 地点にカメラをセットして，実験を開 始した。

(3) 1 被験者が11条件を全て終えた時点で次の被験者と交 代した。 


\subsection{4 被験者}

被験者は神戸大学工学部の男女大学生 20 名（男性 19 名，女性1名）である，被験者の中に避難計画に関する 専門的知識を有した者はいなかった。

\section{2 実験結果および考察}

\subsection{1 広幅員通路の選択率}

各相対比に扔汀丁字路での広幅員通路選択率を図-8 に示す．T字路の左右通路幅員の相対比 1.1 では広幅員 通路の選択傾向は見られない。相対比が 1.3 以上になる と, $75 \%$ 以上の被験者が広幅員通路を選択するようにな り，明らかに広幅員通路選択傾向があるといえる．従っ て, 相対比 1.1 1.3の間に広幅員通路選択傾向が顕在化 する境界域が存在すると考えられる。

相対比 1.3 - 2.5では相対比が大きくなるに従って広幅 員通路の選択率も高くなっており，2.5の時には $90 \%$ を 超える選択率になっている。しかし，これを超えると選 択率が低下する傾向が見られる，以上のことから，広幅 員通路選択傾向が最も顕著に現れるのは左右通路幅員の 相対比が 2.5 程度の時であると判断される。

相対比 3.0 の時に広幅員通路選択率が低下した理由と しては，通路が広すぎたためにその先にある通路が認識 されにくく,行き止まりと感じる被験者がいたためと考 えられる。

\subsection{2 左右通路幅員が等しい場合の選択傾向}

表 -5に示すように，進入路幅員が $10 \mathrm{~cm}$ （実際の空間 で $3.0 \mathrm{~m}$ に相当）のときには左右通路選択率に違いはな い.一方, 進入路幅員が $6 \mathrm{~cm}$ （同 $1.8 \mathrm{~m}$ に相当）のときに 左側通路選択率が $62 \%$, 左側通路の選択傾向が見られ る. 左側通路の選択傾向は従来加指摘されていること であるが，進入路幅員 $10 \mathrm{~cm}$ のとには影響がみられな いことから, 左側通路選択傾向は進入路幅員が狭いとき に，より顕著に現れる傾向であると推測される。

\subsection{3 広幅員通路の配置が選択率に与える影響}

T字路において広幅員通路を左に配置した場合と右に 配置した場合の広幅員通路の選択率を図 -9 に示す。

進入路幅員が $10 \mathrm{~cm}$ （実際の空間で $3.0 \mathrm{~m}$ に相当）のと き，広幅員通路がT字路の左側に配置された場合は相対 比 1.3 のときに最も広幅員通路選択率が高くなり，その 後は選択率 $90 \%$ 程度で推移している。一方, 右側に配置 した場合は相対比が 2.0 に至るまで，相対比が高くなる に従って広幅員選択率も高くなった。

進入路幅員が $6 \mathrm{~cm}$ （同 $1.8 \mathrm{~m}$ に相当）の場合も相対比 1.5 2.0のときには広幅員通路が左側に配置されている 場合の方が, 右側に配置されている場合よりも広幅員通 路選択率が高くなった。

このような違いが現れたのは, 左側通路選択傾向の影

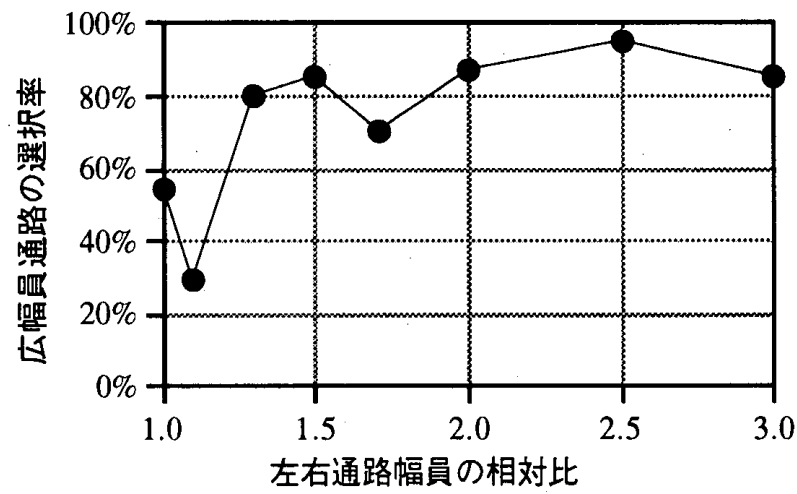

図 -8 情報を制限しなかった場合の広幅員通路選択率

表-5 左右通路幅員が等しい場合の左側通路選択率

\begin{tabular}{|c|c|c|c|c|c|}
\hline \multirow{2}{*}{$\begin{array}{c}\text { 進入路幅員 } \\
\text { de (cm) }\end{array}$} & \multirow{2}{*}{$\begin{array}{c}\text { 左右通路幅貝 } \\
\operatorname{di}(\mathrm{cm})\end{array}$} & \multicolumn{3}{|c|}{ 各通路の選択数（人） } & \multirow{2}{*}{$\begin{array}{l}\text { 左側通路の } \\
\text { 選択率(\%) }\end{array}$} \\
\hline & & 左 & 右 & 合計 & \\
\hline 6.0 & 6.0 & 16 & 10 & 26 & 62 \\
\hline 10.0 & 10.0 & 9 & 11 & 20 & 45 \\
\hline & 合 & 25 & 21 & 46 & 54 \\
\hline
\end{tabular}

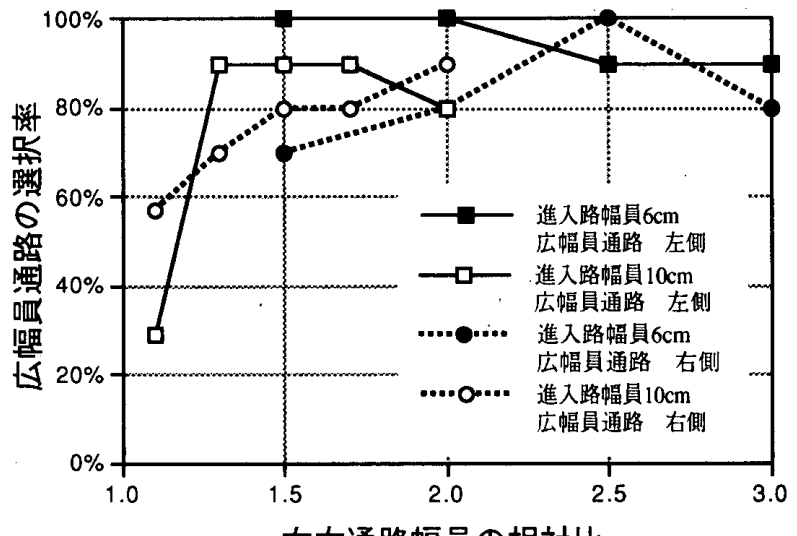

左右通路幅員の相対比

図 -9 広幅員通路の配置による広幅員通路選択率の違い

響が顕在化して，幅員が狭いにもかかわらず左側通路を 選択する被験者が多くなったためと考えられる。

一方，相対比が 1.5 2.5 と大きくなるに従って，広幅 員通路が左にある場合と右にある場合の選択率に差がな くなっていること, 相対比が 2.0 以上の部分ではいずれ の場合も広幅員通路選択率が $90 \%$ 前後で横這いとなって いることから，左側通路選択傾向の影響は相対比が 2.0 以下の場合に顕在化するものと思われる。この特徽は, 特に, 進入路幅員が $10 \mathrm{~cm}$ (実際の空間で $3.0 \mathrm{~m}$ に相当) の ときより，6cm（同 $1.8 \mathrm{~m}$ に相当）のときに顕著である.

また, 左側通路選択傾向の影響は受けているが, 相対 比 1.3 以上の部分では明らかな広幅員通路選択傾向がみ られており，避難時の行動特性として広幅員通路選択傾 向 (向開放性) の方が, 左側通路選択傾向よりも優位に 現れることが確認された。 


\section{4. 避難方向の判断に必要な情報を制限したことの影響} 本研究では，避難方向を判断するための情報を(1)制限 した場合 (VTR 映像実験)，(2)制限しない場合（模型シ ミュレータ実験)，の2つの実験を行った。ここでは, 上 記の2つの奏験方法で得られた結果について比較検討を 行う.

図-10にそれぞれの方法による実験での左右通路幅員 の相対比と広幅員通路選択率との関係を示す.いずれの 実験方法で行った場合でもほほ同様な傾向が得られると

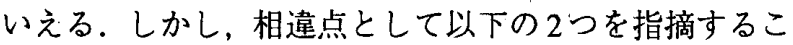
とができる。

(1) VTR 映像による実験の方が模型シミュレータによる 実験に比べ全体的に高い広幅員通路選択率を示してい る.

(2)VTR映像による実験では相対比 3.0 に至るまで広幅員 通路選択率が増加している。一方, 模型シミュレータ による実験では相対比 3.0 のときに広幅員通路選択率 が低下している。

このような違いが生じた理由は以下のように考えるこ とができる。

情報を制限した実験（VTR映像による実験）ではカメ ラの視点が固定されていたため, 当初の設定通り, 被験 者に与えられる情報が直線通路から見た左右通路幅員の みに制限された。このため，通路幅員の違いについての 情報がより明確に認識された。また，視点が固定されて いたため; スクリーンのフレームが左右通路幅員を測る メジャーとなったすすなわち，広幅員通路の場合，T字 路のコーナーが先にスクリーンから見えなくなるため, 通路幅員の広さが強調された。このような状況が広幅員 通路選択傾向を助長したと考えられる。

一方，情報を制限しない実験（模型シミュレータによ る害験）では，被験者に与えられる情報が制限されな かったため, 避難方向の判断にТ字路を曲がった先の状 況など，通路幅員以外の要因が影響を与え，広幅員通路 選択率を引き下げた．さらに，カメラの視点を自由に変 えられたことで, VTR画像の場合のように, スクリーン のフレームが幅員の広さを強調する効果を持たなかった ス.このため, 通路幅員の違い自体の認識が甘くなり，広 幅員通路選択率が抑えられた要因になったと推測され る.

\section{5. まとめ}

避難時の向開放性に焦点を絞り，特に T字路での避難 経路選択に通路幅員が及ばす影響を定量的に把握するた め，以下の $2 つ の$ 奏験を行った。

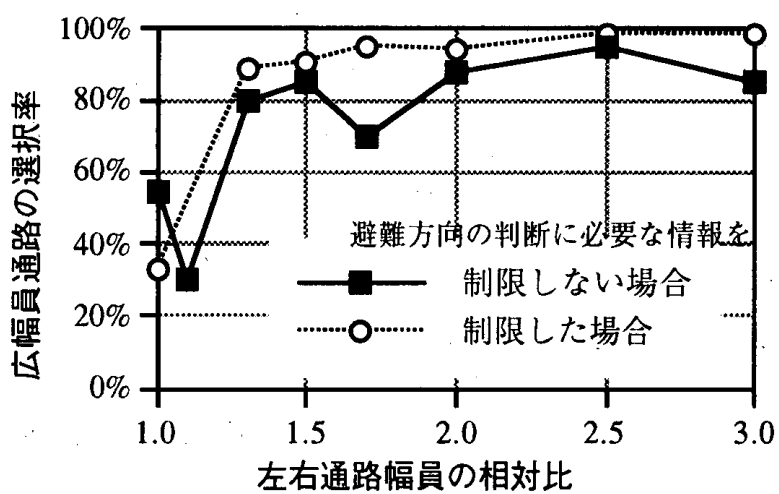

図-10 各実験方法における広幅員通路選択率

・避難方向を判断するための情報を制限した場合（VTR 映像提示による実験）

・避難方向の判断に必要な情報を自由に探索できる場合 （模型シミュレータによる実験）

その結果, 広幅員通路の選択傾向が顕在化するための 条件として以下の点が明らかになった。

(1) T字路における広幅員通路選択傾向の発現境界域は左 右通路の相対比が 1.1〜1.3の間にある.

(2)広幅員通路の選択率が最も高くなるのは左右通路の相 対比が $1.7 〜 2.5$ 程度の時であり，70\%〜90\%以上の避 難者を避難誘導などに頼ることなく自然に広幅員通路 に誘導できる可能性がある。

(3)相対比を 2.5 以上に広くしても，広幅員通路選択率が 高くなることは期待できない。

また，避難行動特性相互の干渉関係として，

(4)広幅員通路選択傾向（向開放性）は, 左側通路選択傾 向よりも優位に現れる.

(5)ずれの実験方法で行った場合でもほほ同様な傾向が 得られるが, 情報を制限した場合の方が広幅員通路選 択傾向は顕著になる。

ことが確認された。

本結果は，避難方向の通路幅員が狭い場合，避難方向 以外の通路の幅員が避難通路に対して相対比 1.3 以上で あれば, 避難通路に避難者が集まるのを期待できないこ とを示唆している．現状の避難計画では，特に避難誘導 によって，狭幅員の通路にも避難者が集まるように計画 している。しかし，避難誘導に失敗した場合，広幅員の 避難経路ではない通路に想定以上の避難者が集中するこ とになり，過度の滞留が発生するなど，避難安全上重大 な問題を起こすことが予想される．以上のことから，避 難安全性を確保するためには，避難方向に広幅員通路を 配置するように計画することが重要であると考えられ る。

本研究で T字路における避難経路選択に通路幅員が及 ほす影響を定量的に示すことができた. 今後は十字路な ど他の通路条件の研究が課題である. 
謝 辞

実験を行うに当たって東京工業大学 大野隆造教授に 多大な御助言，御助力をいただきました。この場をかり て深く感謝の意を表します。

\section{参考文献}

1) 村上處直，中村八郎，高野公男，松島正幸：災害空間の考察（大阪 千日デパート火災) その1〜その3, 日本建築学会大会学術講演梗概集 (九州), PP.503-508, 1971

2）堀内三郎, 室崎益輝, 関沢愛, 日野宗門, 淀野誠三：大洋デパート 火災における避難行動について（その1その2），日本建築学会大会 学術講演梗概集 (北陸), PP.573-576, 1974

3) 日本火災学会：ホテル・ニュージャパンの火災について, 火災, Vol.32 No.3, PP.22-34, 1982

4) 東京消防行政研究会: 火炎の実態から見た危険性の分析と評価一特 異火災事例 112, 全国加除法令出版, P.742, 1981

5) John.L.Bryan : A Review of the Examination and Analysis of the Dynamics of Human Behavior in the Fire at the MGM Grand Hotel, Clark country, Nevada, as Determined from a Selected Questionnaire Population, fire Safety journal, Vol.5 No.3/4, PP.233-240, 1983

6）堀内三郎, 室崎益輝, 淀野誠三, 深谷俊昭：火災時における避難行 動の事例研究, 日本建築学会大会学術講演梗概集 (関東), PP.925-926, 1975

7）室崎益輝：建築防災·安全, 鹿島出版会, p.192, 1993

8) 北後明彦: 建物火災における避難行動事例の類型化とその規定要因

の構造，日本建築学会計画系論文報告集，No.347，PP.28-33，1985

9) 西田佳弘, 㻕内三郎, 高橋昭子: 群采の歩行速度と群衆密度との関
係に関する研究一大阪梅田阪急電車駅構内にお忛万階段効果流動につ いて一, 日本建築学会近畿支部研究報告集, PP.321-324, 1984

10）神忠久：火炎時の人間の行動・生理的反応，建筑技術，No.412, PP.85-91, 1985

11）北後明彦：煙の中における人間の避難行動実験一避難経路選択お よび歩行速度に関する実験的研究一, 日本建築学会計画系論文報告集, No.353, PP.32-38, 1985

12) Jake Pauls : Movement of People in Buildings, An International Review of Two Decades of Reserch and Technology Transfer, CIB86, Vol.7, PP.2982-2991, 1986

13）多田智佳, 大西一協, 室崎益輝：地下街に扔ける避難経路選択行 動に関する研究, 日本建築学会近畿支部研究報告集計画系, No.34, PP.549-552, 1994

14）飯田稳，村井健祐：避難行動に関する研究一年代層別に見た避難 行動特性とその対策一, 日本火災学会論文集, Vol.42 No.2, PP.17-28, 1995

15）林広明，室崎益輝，西垣太郎：避難経路の想起に影響を与える㞬 間的特徵に関す万研究, 日本建築学会計画系論文集, No.476, PP.1-7, 1995

16）舟梮國男：対称的な 2 経路の選択に関する実験的研究，日本建築 学会計画系論文報告集, No.427, PP.65-70, 1991

17) M.J.O'Neill : Effects of Familiarity and Plan Complexity on Wayfinding in Simulated Buildings, Journal of Environmental Psychology, Vol.12, PP.319-327, 1992

18）林広明, 池香由華, 室崎益輝, 西垣太郎：T字路における避難方 向の選択に通路幅員が与える影響に関する研究 その1〜その 2 , 日本 建築学会大会学術講演梗概集 (北海道), PP.213-216, 1995

（1996年 3 月 10 日原稿受理， 1996年 5 月 9 日採用決定） 